\title{
Examining The Relationship Between Inequalities In Gender Wage And Economic Growth In Pakistan
}

\author{
Asghar Ali \\ Applied Economics Research Centre \\ University of Karachi \\ Li Jun Jiang \\ School of Economics \\ Jilin University
}

\begin{abstract}
Gender equality is not only a policy reform agenda for developing countries but also an important goal of Millennium Development Goals. With respect to all socio-economic indicators, the development history demonstrates extremely gloomy image of gender inequality in Pakistan. With this background this paper investigates the nexus between wage inequality and economic growth and detects co-integration between gender wage differential and economic growth using ARDL bound test. It is confirmed from the empirical results that there exists long-run relationship between economic growth and wage differential. The findings of unrestricted error correction model indicate that the wage inequality showed negative and significant impact on economic growth in the long run. The results of this study showed dissimilarity with the findings of Seguino (2000) that there is existed constructive association between wage inequality and economic growth. An important finding from the present examination is that the gender wage gap is detrimental for the process of growth in long run. Policies should be made to reduce gender wage gap. Such government policy should be designed which could address and adjust economic priorities in the face of changing global economic realities and provide comprehensive framework for conducive environment for gender.
\end{abstract}

Keywords: Gender Equality, Economic Growth, Favourable Environment for Gender

$$
\begin{aligned}
& \text { تلخيص }
\end{aligned}
$$

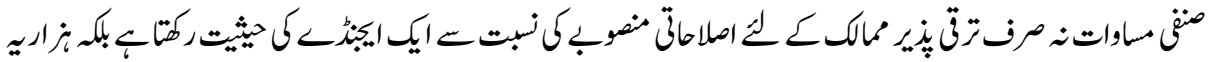

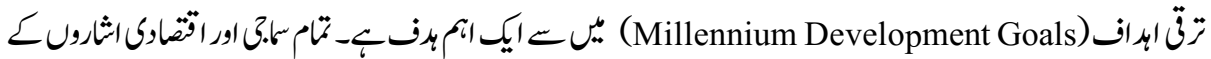

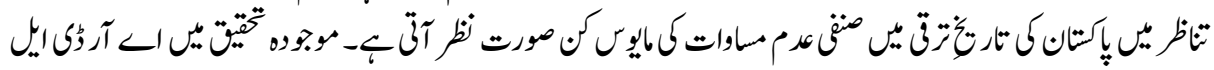

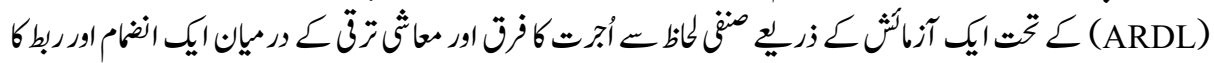

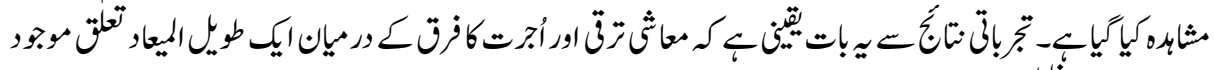

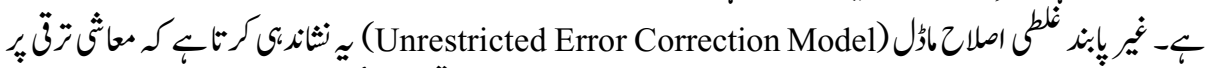

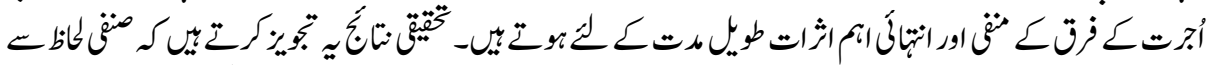

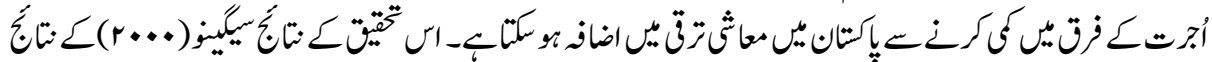

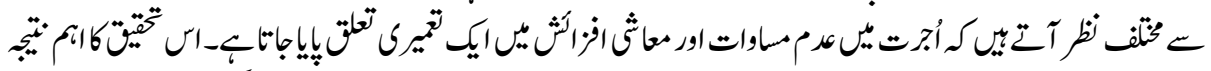

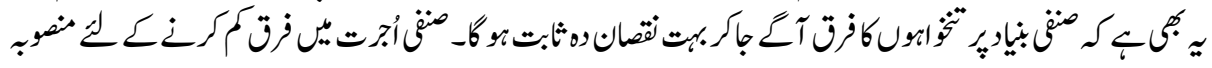




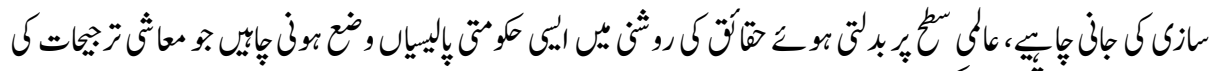

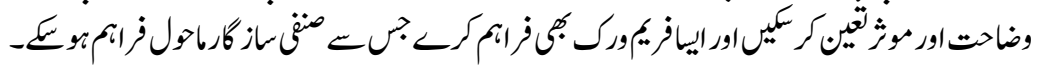

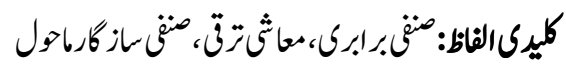

\section{Introduction}

The noticeable discrimination among men and women is now fairly well-established, as it is wide-spread in several spheres of life. This discrimination can be exemplified by exploring several domains. While considering this imbalanced attitude towards women, one can clearly see that for example, there is a clear inequity in the wage scales among men and women. Women are provided only a few opportunities at the workplace, given less right to use and be in charge of resources, and are unduly represented in the political vista. The character and degree of this disparity and difference varies noticeably across countries. As mentioned above, one of the most clear instance in this perspective is disparity and imbalance in the wages are on the basis of gender. It can be observed that women are earning less than men for similar nature of work, on average, and the differential varies across nations.

Gender equality is not only a policy reform agenda for developing countries but also an important goal of Millennium Development Goals. On principal, disparity on the basis of gender cannot be accepted. Although, gender inequality is a global phenomenon, it can be experiential in emerging countries over and above in developed world. With respect to all socio-economic indicators, the development history demonstrates extremely gloomy image of gender inequality in Pakistan. For instance, according to the Gender Empowerment Measurement (GEM) Pakistan ranked at 66, out of 75 countries one of the justification for gender disparity is differential in labor market primarily in wages on the basis of gender (Human Development Report, 2006).

The gender segregation in the labor market in Pakistan is characterized by the immensity of females working either in non-market sectors like homes or the informal sector. On the other hand women working in formal sectors either public or private are usually engaged in "female intensive industries." A few such activities can be exemplified as shrimp processing and pharmaceuticals. So gaining an insight into such sort of labor market segregation can lead one to the revelation of fact that there are differences in wages and discrimination against women. It is obvious that women receive lower wages than men when they are employed on equal job status, hours of work, type of occupation and status of employment. Although the labor code of the country sets conditions as part of agreement to pay equally for equal work, but very little is known about the actuality which lies in the pay levels for men and women. 
Social scientists and economists are concerned in reducing the existing gender inequalities not only because it is related to well-being but it also has certain economic consequences. The gender wage differential affects both economic growth and economic development of the country.

Seguino (2000) ended up being in favor of gender wage differential and stated that it might be essential for economic growth. Lower wage of female compare to male in semiindustrialized export oriented economies, may promote investment and ultimately escort to growth in the economy. Mitra-Kahn and Mitra-Kahn (2008) favored Seguino and stated that variations and differences are the reasons of increase in growth in the beginning developmental phases. So this turns out to be a clear contradiction of the studies which states that gender disparity in education or access to employment opportunities are damaging for growth.

Economic growth can be effected by the gender wage differentials through the cost of production. For instance, lower female wage will reduce the unit cost of production and ultimately increase the competitiveness of a country and support expansion in exports. Further, it stimulates investment by increasing the profits of the producers and ultimately causes to foster the economic growth. However, contradicting argument can also be perceived to determine the correlation between economic growth and gender wage inconsistencies. Many of the researchers have made attempt but unable to produce any conclusive results of the outcome of gender wage inequality and economic growth. Hence, there is a need to further explore the nexus between inequality in the wage and growth.

There is extensive literature on the factors of economic growth and literature evident various significant factors for economic growth including capital, human capital technology, saving rate, investment, trade openness and institutional quality but there is increasing interest of the researchers in examining the relation between gender wage disparity and economic growth.

Mostly literature on the relevant subject is based on cross country study. In order to formulate sound policy, it would be more important to perform country specific analysis. To the best knowledge of the author, no effort has been made to evaluate the relation between the gender wage disparity and economic growth in Pakistan. We explore this nexus by employing ARDL method.

The plan of the paper is organized as follows: The trend in gender wage gap indicators are presented in section II. Review of literature is provided in section III. Data sources and econometric methodology is discussed in section no. IV. The reports and discussion on the empirical results is given in Section V. And finally, the conclusion of the paper and main findings are presented in Section VI.

\section{Wage Differential Trend Analysis}

The Average wage of male and female are plotted in Figure 1. The figure highlights the difference in the wages of male and female. It is clear from the figure that the females are earning less than the males during the entire period of the analysis. It is clear from the 
plot that the male wage is 10 times more than the female wage over the time. Further, the absolute difference between the female average earning and male average earning become wider after 2005 .

Figure 1: Average Wage of Male/Female - 1991-2012

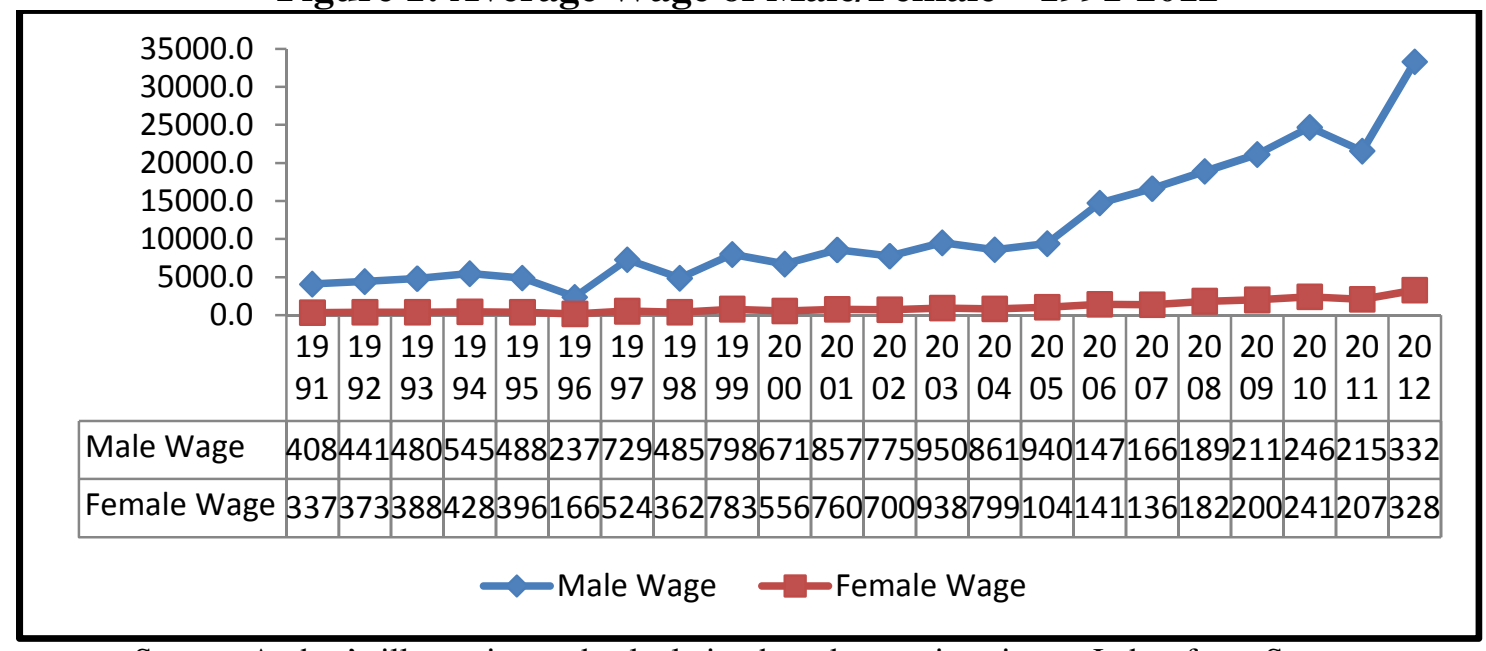

Source: Author's illustration and calculation based on various issues Labor force Survey

The growth rate of average wage of male and female is given in Figure 2. The growth rate of average wage of male and female are showing similar trend over the time.

Figure 2: Growth Rate of Average Wage of Male/ Female - 1991-2012

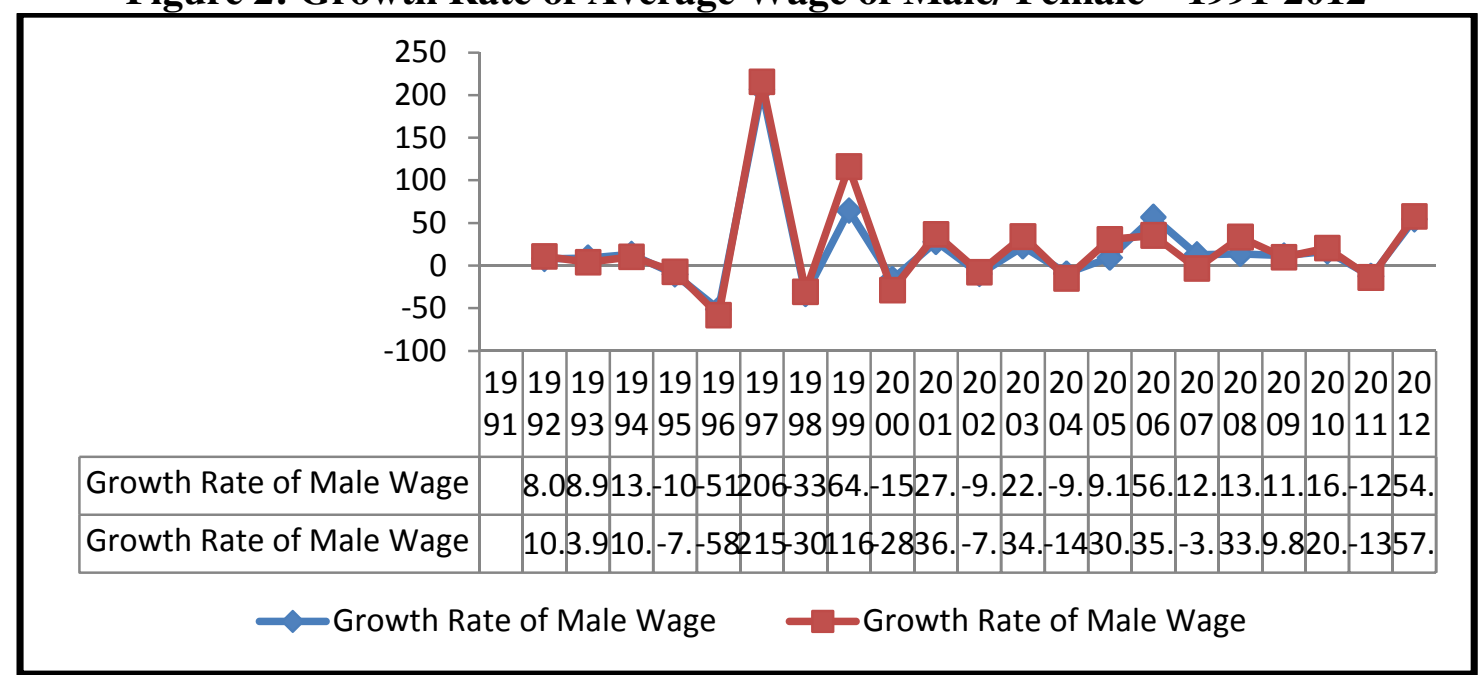

Source: Author's illustration and calculation based on various issues Labor force Survey

The wage differential is plotted in Figure 3 which is calculated by dividing average female wage by the average male wage. It can be observed that the wage differential 
between female and male is very high during the period of analysis as the value of wage closer to zero (less than 0.09) in all the years. If the value is closer to one it indicates that the wage differential between female and male is low and if the value of wage differential is closer to zero it highlights that the wage differential is very high.

Fig.3 Average wage of Male and Female

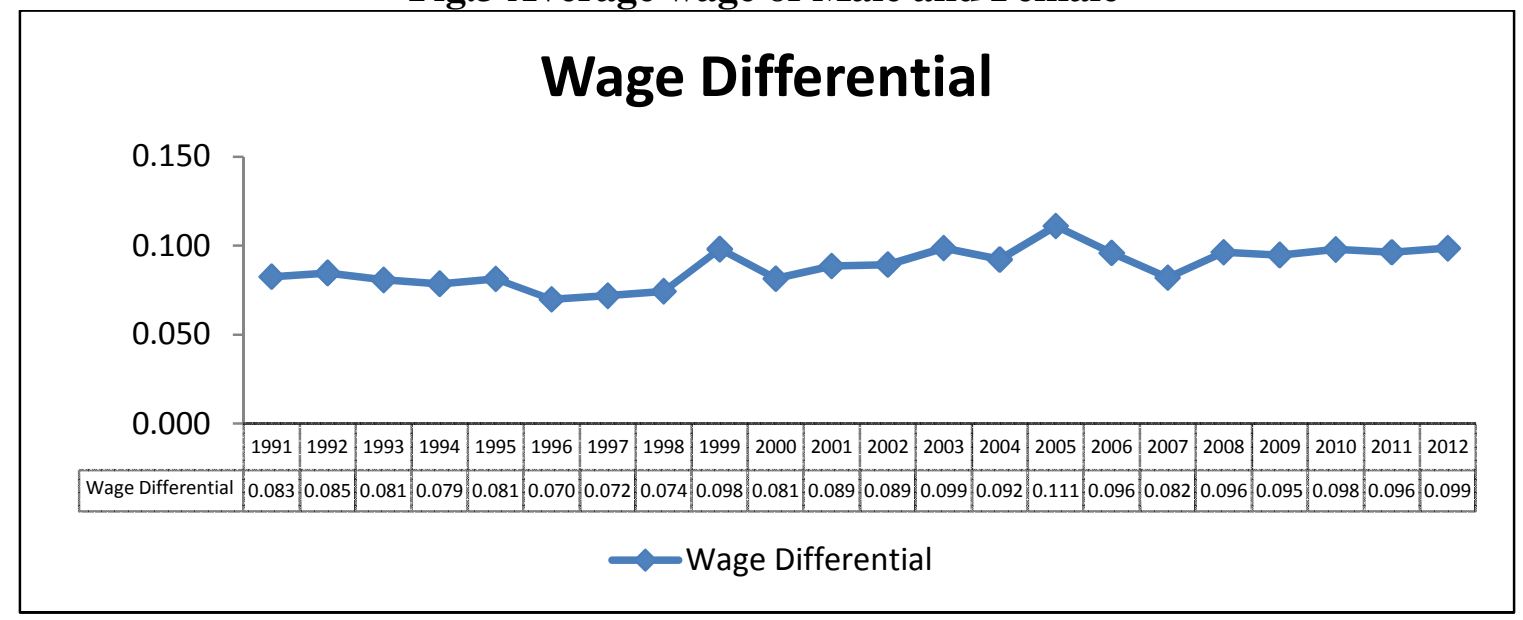

Source: Author's calculation using Labor force Survey

\section{Review of Literature}

Gender inequality and economic growth display a multifaceted relation. There are numerous probable direct and indirect links between the two. This is an indubitable fact that difference in education with respect to gender is highly damaging to the growth and sustainable development of a nation. A healthy amount of literature which is produced in this regard certainly suggests that if the gender inequality persists, it will trim down average human capital and ultimately damaging for economic growth. Knowles et al., (2002) suggested that given the diverse talents among children, the marginal returns to educate girl should be greater than boys that are inefficient if education is provided to females that have equal potential. Coefficient of growth regression for female education showed negative results, this was established by Barro and Lee (1994). Dollar and Gatti, (1999) suggested that this is a consequence of including some outliers whereas Klasen, (2002) concluded as a result of multicolinearity between female and male school achievement. Many researchers, including Galor and Weil (1996), Schultz (1997) and Lagerlöf (2003) highlighted that there might be some supplementary effects of female education on factors that can foster economic growth such as it can decline fertility, reduce child mortality or promote education of the children.

Results pertaining to females' access to employment are also not very healthy. Inference between growth and employment gap was explored by Klasen and Lamanna (2009). During 1960-2000, they conducted a cross-country study and concluded that for Middle East and North Africa, high cost of low female labor force participation found to be one 
of the most important determinant in explaining the growth differences in East Asia. Seguino (2000) explained that discrepancy in gender wage might promote for economic growth. She proposed that gender differential have positive impact on growth for semiindustrialized export-oriented countries.

\section{Data Source and Methodological Framework}

\section{Data Source}

This research paper utilizes time series information for the period of 1991-2012. The information on GDP growth (EG), gross fixed capital formation as a percentage of GDP $(\mathrm{KF})$ as proxy of investment and trade share as \% GDP as proxy of openness is gathered from World Development Indicators (WDI). Various issues of Economic Survey of Pakistan were considered to collect information on labour force. Labour Force Surveys (1991-2012 are utilized to assemble information on wages for male and female and to generate series of wage differential (WN). The descriptive statistics is presented in Table 1.

Table: 1

Descriptive Statistics

\begin{tabular}{|c|c|c|c|c|}
\hline Variables & Mean & $\begin{array}{c}\text { Standard } \\
\text { Deviation }\end{array}$ & $\begin{array}{c}\text { Maximum } \\
\text { Value }\end{array}$ & $\begin{array}{c}\text { Minimum } \\
\text { Value }\end{array}$ \\
\hline EG & 4.02 & 1.94 & 7.71 & 1.01 \\
\hline LF & 45563779 & 10345733 & 63777830 & 31704892 \\
\hline KF & 16.24 & 1.73 & 19.24 & 12.52 \\
\hline TO & 34.19 & 2.93 & 38.91 & 28.13 \\
\hline WN & 0.08 & 0.01 & 0.11 & 0.07 \\
\hline
\end{tabular}

Source: Author's illustration

\section{Methodology}

This study explores the long and short run impact of gender wage differential on economic growth with the help of following empirical model:

$$
E G_{t}=\alpha_{1}+\alpha_{2} L F_{t}+\alpha_{3} K F_{t}+\alpha_{4} T O_{t}+\alpha_{5} W N_{t}+\mu_{t} \ldots \ldots . . E(1)
$$

Here, the ARDL approach is applied to investigate the above mentioned impact. The benefits of choosing the ARDL approach for the purpose above other conventional cointegration approaches such as Engle and Granger (1987), Johansen and Juselius (1990) and Johansen, $(1991,1992)$ are proven by the empirical researches of the recent decade. It works more appropriately both at level $\mathrm{I}(0)$ and first difference $\mathrm{I}(1)$. ARDL approach is better to adopt because:

i) It is more appropriate to be used and to generate more reliable results when working with small sample sized data sets when compared with other conventional techniques to accomplish the same task. 
ii) It also provides the short run adjustment without losing the long run information (Pesaran and Shin 1999) and Pesaran (2001).

ARDL representation of equation (1) is formulated as follows in order to assess the impact of wage differential on growth,

$$
\begin{aligned}
& \Delta E G_{t}=\chi+\sum_{i=1}^{p} \psi_{i} \Delta E G_{t-i}+\sum_{i=1}^{p} \varphi_{i} \Delta L F_{t-i}+\sum_{i=1}^{p} \pi_{i} \Delta K F_{t-i}+\sum_{i=1}^{p} \gamma_{i} \Delta T O_{t-i}+\sum_{i=1}^{p} \phi_{i} \Delta W N_{t-i} \\
& +\eta_{1} E G_{t-1}+\eta_{2} L F_{t-1}+\eta_{3} K F_{t-1}+\eta_{4} T O_{t-1}+\eta_{5} W N_{t-1}+\mu_{t} \ldots \ldots \ldots \ldots \ldots \ldots(2)
\end{aligned}
$$

Where,

\begin{tabular}{|l|}
\hline$\chi$ is drift factor \\
\hline$u t$ is the white noise residuals \\
\hline$\Delta$ denotes the first difference operator \\
\hline$\eta$ is representing the respective long-run estimates of given model \\
\hline$\Psi, \varphi_{i}, \pi_{i}, \gamma_{i}$ and $\phi_{i}$ represents short-run dynamic coefficients \\
\hline
\end{tabular}

- To estimate the long run relationship among the variables, bound testing procedure is used.

- The bound testing procedure is based on the Wald-test (F-statistic).

- The Wald test (F-statistic) is a test of the hypothesis of no co-integration among the variables against the existence or presence of co-integration among the variables, denoted as:

H0: $\eta_{1}=\eta_{2}=\eta_{3}=\eta_{4}=\eta_{5}=0$ i.e., there is no co-integration among variables

H1: $\eta_{1}=\eta_{2}=\eta_{3}=\eta_{4}=\eta_{5} \neq 0$ i.e., there is co-integration among variables

As Pesaran et al (2001) uses the two critical values (lower and upper) for co-integration test, he says that when the calculated F- statistic estimated through Wald test is greater than the upper bound critical value, then the $\mathrm{HO}$ is rejected, which indicates that there is long run relationship among variables. If the estimated F-statistic is below the lower bound critical value, then the HO cannot be rejected, which reveals that there is no cointegration among the variables. When the computed F- statistics falls between the lower and upper bound, then the results are inconclusive. When the long run relationship exists among the variable, then there is error correction representation. Thus, equation (2) in the ARDL version of the error correction model can be expressed as equation (3):

$$
\begin{aligned}
& \Delta E G_{t}=\delta+\sum_{i=1}^{p} \psi_{i} \Delta E G_{t-i}+\sum_{i=1}^{p} \varphi_{i} \Delta L F_{t-i}+\sum_{i=1}^{p} \pi_{i} \Delta K F_{t-i}+ \\
& \sum_{i=1}^{p} \gamma_{i} \Delta T O_{t-i}+\sum_{i=1}^{p} \varphi_{i} \Delta W N_{t-i}+\theta E R_{t-1}+\mu_{t} \ldots \ldots \ldots \ldots E_{\text {. }} \ldots \ldots
\end{aligned}
$$


Where $\theta$ is the parameter of speed of adjustment towards long run and ER is the residuals that estimated from equation (2) .The coefficient of error correction term (ER) in the model indicates the speed of adjustment back to long run equilibrium after a short run shock. To ensure the goodness to fit of the model, the diagnostic such as the serial correlation, functional form, normality and heteroscidasticity and stability tests have also been employed to get parsimonious model. In order to select optimal lag length for each variable, the ARDL approach estimates $(q+1) m$ number of regressions,

where,

$q$ is the maximum number of lags, and

$m$ is the number of variables in the model.

The number of lags is selected on the basis of Akaike's Information Criteria (AIC) frequently used in the literature.

\section{Empirical Results}

We first check the order of integration of the variable by employing Augmented Dickey Fuller Test for analysis as if the order of integration of the variables is I(2) or above then the calculated F - Statistics will be spurious (Ouattara, 2004).

Table: 2

Test of the Unit Root Hypothesis

\begin{tabular}{|c|c|c|c|c|}
\hline \multirow[b]{2}{*}{ Variables } & \multicolumn{2}{|c|}{ ADF Test with Intercept } & \multicolumn{2}{|c|}{$\begin{array}{l}\text { ADF Test with Intercept } \\
\text { and trend }\end{array}$} \\
\hline & $\mathrm{t}$-Statistic & $\mathrm{K}$ & $\mathrm{t}$-Statistic & $\mathrm{K}$ \\
\hline EG & $-3.41 * *$ & 4 & $-3.44 * *$ & 4 \\
\hline LF & $-4.14 * *$ & 0 & $-4.11 * *$ & 0 \\
\hline $\mathrm{KF}$ & -1.22 & 0 & -1.85 & 0 \\
\hline TO & -2.48 & 0 & -2.61 & 0 \\
\hline WN & -2.45 & 0 & $-3.81 * *$ & 0 \\
\hline$\Delta \mathrm{EG}$ & $-5.55^{*}$ & 0 & $-5.39 *$ & 0 \\
\hline$\Delta \mathrm{LG}$ & $-5.25^{*}$ & 1 & $-5.17 *$ & 4 \\
\hline$\Delta \mathrm{KF}$ & $-3.72 * *$ & 0 & $-3.61 * *$ & 0 \\
\hline$\Delta \mathrm{TO}$ & $-6.37 *$ & 0 & $-6.19 *$ & 0 \\
\hline$\Delta \mathrm{WN}$ & $-7.14 . *$ & 0 & $-6.96^{*}$ & 0 \\
\hline
\end{tabular}

The results reported in Table 1 spell out non stationary of investment (KF), trade openness (TO) and wage inequality (WN) at level $\mathrm{I}(0)$ whereas economic growth (EG) and labour force(LF) are stationary at level $\mathrm{I}(0)$. However, all underling series are 
stationary at first difference $\mathrm{I}(1)$. It is clear from results that series are mix of both $\mathrm{I}(0)$ and I(1), and considered as appropriate for the ARDL assessment.

This study has applied Wald Test to explore the relationship between wage inequality among genders and economic growth, we applied Wald Test. To estimate the model, Akiake Information Criterion (AIC) is exercised to select the optimal lag length to estimate the model and on the basis lowest value of the AIC, it is concluded that lag three are selected. The results are stated in Table - 2 that conclude long run relationship between wage inequality and economic growth.

Table: 3

Long Run Relationship

\begin{tabular}{|c|c|}
\hline Variables & F-Statistics \\
\hline $\mathrm{F}(\mathrm{EG} / \mathrm{LF}, \mathrm{KF}, \mathrm{TO}, \mathrm{WN})$ & $5.34^{*}$ \\
\hline
\end{tabular}

It is difficult to accept that there is a null hypothesis of no co-integration between economic growth (EG) and wage inequality (WN) on the basis of computed F - Statistics. The computed F - Statistics at 1 percent level of significance are more as compared to the higher bound critical value. The estimated F-statistic was also matched with the critical values that give an explanation for small sample sizes were presented by Narayan (2005) ${ }^{1}$. The ARDL bound test' experimental findings expose that there is a constant long-run connection between economic growth (EG) and wage differential (WN) ${ }^{2}$.

The long run estimates are estimated using unrestricted error correction model which is based on the assumption set by Pesaran et al. (2001). Results reported in table 3 indicate that the long run estimate of wage inequality is negative and significant impact on growth. The finding suggests that reduce gender wage gap for fostering economic growth in Pakistan. Therefore, government and policy makers should direct their efforts towards on this issue. The empirical results further reveal that free and open markets, domestic investment and educated and skill labor force are also important long run determinants for growth of Pakistan.

Table: 4

Long Run Estimates

\begin{tabular}{|c|c|c|c|}
\hline LF & KF & TO & WN \\
\hline $3.36^{* *}$ & $0.58^{*}$ & $0.17 * *$ & $-0.76^{*}$ \\
\hline
\end{tabular}

$* *$ and $*$ indicate significance level at $5 \%$ and $1 \%$ respectively

Various diagnostic test and the results of ARDL for the error correction model are reported in Table 4. 
Table: 5

Error Correction Model (ECM) Estimates

\begin{tabular}{|c|c|}
\hline \multicolumn{2}{|c|}{ Dependent Variable=EG } \\
\hline Regressors & Estimated Coefficients \\
\hline Constant & 0.10 \\
\hline$\Delta E G t-4$ & 0.17 \\
\hline$\triangle L F$ & 0.02 \\
\hline$\Delta K F$ & $0.67 *$ \\
\hline$\Delta T O$ & $0.11 * *$ \\
\hline$\Delta W N$ & -0.38 \\
\hline$E C T(-1)$ & $-0.78 * *$ \\
\hline Diagnostic Tests & P-Value \\
\hline Serial Correlation & 0.15 \\
\hline Heteroscedasticity & 0.87 \\
\hline Functional Form & 0.16 \\
\hline Normality & 0.88 \\
\hline
\end{tabular}

The speed of adjustment in equilibrium from short run period to long run is represented by the coefficient of ECT term. The results pointed out that the ECT coefficient has negative sign and significant. This indicates existence of long run relationship among underling series (Bannerjee et al., 1998). During the short run ECT coefficient has a value of (-0.78) which means divergence in growth during short run is adjusted by 78 percent in the long run.

An inverse relationship between wage inequality and economic growth is also found in the short run in the deep-rooted relationship among them, however this association is insignificant. Increase in investment is associated positively and significantly related with growth. Similarly, impact of trade openness policies has positive and significant effect on growth while growth in labor force has constructive impact on economic growth but its impact is minimal with significance in short run.

\section{Conclusions}

This paper investigates the nexus between wage inequality-growth if we consider the situation according to the case of Pakistan. On conducting the empirical analysis for short run and the long run, it is comprehended that wage inequality turned out to be inversely related with the economic growth. The results of this study showed dissimilarity with the findings of Seguino (2000) that there is existed constructive association between wage inequality and economic growth. But these findings are coherent and in harmony with the study of Schober T. \& Ember R. W (2011). 
The controversy among wage inequality and economic growth has owned its permanent place in the literature over a longer period of time. It is noticeable that women has lack of access to education and labour market and this will certainly result as unfavorable and disadvantageous to the overall development and growth. On internationally comparing gender wage discrimination, we could easily claim that no other factor could hamper economic development as greatly as the gender wage discrimination does. Gender equality - in return - is to its highest degree, the factor which can positively contribute for the betterment and development of economy.

Therefore, this research evaluates the consequences of gender wage inequality on economic growth in Pakistan, which in return not only proves the strength of gender inequality because of its built - in assessment moreover in accordance with the influential assessment for economic growth. It can be observed from the statistics gender specific information is depressing in Pakistan. The constitution of Pakistan although certainly approves equal rights and treatment for all people of society but unfortunately the ground reality is different. Women lack their rights and own fewer privileges in almost every field of life as compared to men. They obtain less right of entry to health, education and employment opportunities and could maintain very insufficient rights. These and many other unequal behaviors have left women undemonstrative and leave with restricted role to play in the economic development of Pakistan. Gender inequality is multifaceted and complex in nature. Therefore, a holistic approach is required to handle this matter. Therefore, it can be concluded that there is a need to formulate not only the public policies but access of women to the education, health and employment opportunities should also be enhanced.

Finally, an important finding from the present examination is that the gender wage gap is detrimental for the process of growth in long run. Policies should be made to reduce gender wage gap. Such government policy should be designed which could address and adjust economic priorities in the face of changing global economic realities and provide comprehensive framework for conducive environment for gender.

\section{End Notes}

1. Pesaran et al. (2001) lower and upper bound critical values are 2.12-3.23 at 90\%, $2.24-3.61$ at $95 \%$, and $3.15-4.43$ at $99 \%$ Narayan (2005) also calculate a set of critical values for small sample sizes are $2.353-3.599$ at $90 \%, 2.797-4.211$ at $95 \%$, and 3.800-5.643 at $99 \%$.

2. We also employ the Johensen cointegration method for long run relationship between economic growth and wage inequality to check the robustness of our results (See results in appendix) 


\section{References}

Banerjee, A., Dolado, J. \& Mestre, R. (1998). Error-Correction Mechanism Tests for Cointegration in a Single-Equation Framework. Journal of Time Series Analysis, vol.19, pp.267-283. doi: 10.1111/1467-9892.00091

Barro, R. J., \& Lee, J.-W. (1994). Sources of Economic Growth. Carnegie-Rochester Conference Series on Public Policy, vol.40, pp.1-46.

Dollar, D., Gatti, R. (1999). Gender Inequality, Income and Growth: Are Good Times Good for Women? Policy Research Report on Gender and Development Working Paper, No. 1, Washington, D.C.: World Bank.

Engle, R. F. \& Granger, C.W.J. (1987). Cointegration and Error-Correction: Representation, Estimation, and Testing. Econometrica, vol.55, pp.251-276.

Esteve-Volart, B. (2009). Gender Discrimination and Growth: Theory and Evidence from India. Mimeo, York University, Toronto

Galor, O. \& Weil, D. N. (1996). The Gender Gap, Fertility, and Growth. American Economic Review, vol.86:1, pp.374-387.

Human Development Report (2006). Beyond Scarcity: Power, Poverty and the Global Water Crisis, http://hdr.undp.org/sites/default/files/reports/267/hdr06-complete.pdf.

Johansen, \& Juselius (1990). Maximum Likelihood Estimation and Inference on Cointegration with Applications the Demand for Money. Oxford Bulletin of Economics and Statistics, vol.52:2, 169-210

Johansen, S. (1992). Determination of Cointegration Rank In The Presence Of A Linear Trend. Oxford Bulletin of Economics and Statistics, vol.54,pp.383-397. doi: 10.1111/j.1468-0084.1992.tb00008.x

Johansen, Søren (1991). Estimation and Hypothesis Testing of Cointegration Vectors in Gaussian Vector Autoregressive Models. Econometrica, Wiley, Econometric Society, vol.59:6, pp.1551-1580. doi:10.2307/2938278.

Klasen, S. (2002). Low Schooling for Girls, Slower Growth for All? Cross-Country Evidence on the Effect of Gender Inequality in Education on Economic Development. World Bank Economic Review, vol.16:3, pp.345-373. 
Klasen, S. \& Lamanna, F. (2009). The Impact of Gender Inequality in Education and Employment on Economic Growth in Developing Countries: Updates and Extensions. Feminist Economics, vol.15:3, pp.91-132.

Knowles, S., Lorgelly, P. \& Owen, D. (2002). Are Educational Gender Gap a Break on Economic Development? Oxford Economic Papers, vol.54, pp.118-149.

Labour Force Survey (1991-2012). Federal Bureau of Statistics, Government of Pakistan.

Lagerlöf, Nils-Petter (2003). Gender Equality and Long-Run Growth. Journal of Economic Growth, vol.8:4, pp.403-426 doi 10.1023/A:1026256917489

Mitra-Kahn, B. H. \& Mitra-Kahn, T (2008). Gender Wage Gaps and Growth: What Goes Up Must Come Down. Manuscript Submitted for Publications.

Ouattara, B. (2004), Modelling the Long Run Determinants of Private Investment in Senegal, The School of Economics Discussion Paper Series 0413, The University of Manchester, Manchester.

Pesaran, M. H., Shin, Y. \& Smith, R. J. (2001), Bounds Testing Approaches to the Analysis of Level Relationships. Journal of Applied Economics, vol.16, pp.289326. doi: 10.1002/jae.616

Schober, T. \& Winter-Ebmer, R. (2011). Gender Wage Inequality and Economic Growth: Is there Really a Puzzle? World Development. doi:10.1016/j.worlddev.2011.05.001.

Schultz, P. T. (1997). Demand for Children in Low-Income Countries. In M Rosenzweig, \& O. Stark (Eds.), Handbook of Population and Family Economics. Amsterdam: Elsevier.

Seema, Narayan \& Paresh, Kumar Narayan (2005) An Empirical Analysis of Fiji's Import Demand Function, Journal of Economic Studies, vol.32:2, pp.158-168, doi: 10.1108/01443580510600931

Seguino, S. (2000). Gender Inequality and Economic Growth: A Cross-Country Analysis. World Development, vol.28:7, pp.1211-1230. 
Asghar Ali is Staff Economist in the Applied Economics Research Centre, University of Karachi and Ph.D. fellow at Jilin University China.

Li Jun Jiang is Dean in the School of Economics, Jilin University, China. 